\title{
Efektivitas Modul Kesetimbangan Kimia Berbasis Guided Discovery Learning terhadap Hasil Belajar Peserta Didik
}

\section{The Effectiveness of Chemical Equilibrium Module Based on Guided Discovery Learning for Students' Learning Outcomes}

\author{
E Y F Said ${ }^{1}$ and Yerimadesi ${ }^{1^{*}}$ \\ 1 Program Studi Pendidikan Kimia, Jurusan Kimia, Universitas Negeri Padang, \\ J1. Prof. Dr. Hamka, Air Tawar Barat, Padang Utara, Sumatera Barat, Indonesia 25171 \\ *yeri@fmipa.unp.ac.id
}

\section{ARTICLE INFO \\ Received on: \\ 31 May 2020 \\ Revised till: \\ 22 June 2020}

Accepted on:

01 August 2020

Publisher version published on:

28 February 2021

\begin{abstract}
This study aims to analyse the effectiveness of the chemical equilibrium module based on guided discovery learning on the learning outcomes of students. The study design uses a randomized control-group pretest-posttest design with quasi-experimental type. The population consisted of grade XI students of SMAN 1 Tigo Nagari in the 2019/2020 school year and samples were taken using simple random sampling technique. The research instrument was in the form of multiple choice tests, the data were analysed by n-gain test and hypothesis testing by $t$ test. Based on the analysis of the data obtained n-gain experimental class is higher than the control class with a medium category and the hypothesis test obtained sig (2-tailed) less than 0,05. Analysis of these data concludes thehypothesisis acceptedinotherwordstheuseofachemicalequilibriummodulebased on guided discovery learning is effective in improving student learning outcomes in class XI of SMAN 1 Tigo Nagari.
\end{abstract}

\section{KEYWORDS}

Chemical Equilibrium, Effectiveness, Guided Discovery Learning,

Learning Outcomes, Modules

\begin{abstract}
ABSTRAK
Penelitian ini bertujuan menganalisis efektivitas modul kesetimbangan kimia berbasis guided discovery learning terhadap hasil belajar peserta didik. Rancangan penelitian menggunakan randomized control-group pretest-posttest design dengan jenis eksperimen semu. Populasi terdiri dari peserta didik kelas XI SMAN 1 Tigo Nagari tahun ajaran 2019/2020 dan sampel diambil menggunakan teknik simple random sampling. Instrumen penelitian berupa tes dalam bentuk pilihan berganda, data dianalisis dengan uji $n$-gain dan uji hipotesis dengan uji t. Berdasarkan analisa data diperoleh $n$-gain kelas eksperimen lebih tinggi daripada kelas kontrol dengan kategori sedang dan uji hipotesis yang didapatkan sig(2-tailed) kurang dari 0,05. Analisis data tersebut menyimpulkan hipotesis diterima dengan kata lain penggunaan modul kesetimbangan kimia berbasis guided discovery learning efektif terhadap peningkatan hasil belajar peserta didik kelas XI SMAN 1 Tigo Nagari.
\end{abstract}

\section{KATA KUNCI}

Kesetimbangan Kimia, Efektivitas, Guided Discovery Learning, Hasil Belajar, Modul 


\section{PENDAHULUAN}

Berdasarkan kurikulum 2013 pembelajaran didasarkan pada pendekatan saintifik. Pendekatan saintifik yaitu suatu proses pembelajaran yang mampu mengembangkan kreativitas, kemampuan berpikir kritis dan inovatif peserta $\operatorname{didik}^{[1]}$. Pendekatan saintifik diimplementasikan dalam pembelajaran membutuhkan model pembelajaran seperti Inquiry Learning, Problem Based Learning dan Guided Discovery Learning (GDL).

GDL yaitu salah satu model pembelajaran yang mampu meningkatkan motivasi, pemahaman dalam proses belajar ${ }^{[2]}$, meningkatkan hasil kognitif ${ }^{13-4]}$, kemampuan dalam memecahkan masalah kimia $^{[5]}$, prestasi dalam kimia $^{[6]}$, dan merupakan metode pengajaran yang paling efektif ${ }^{1-8]}$. Salah satu bahan ajar yang sesuai untuk mendukung penerapan model GDL dalam pembelajaran yaitu modul.

Pembelajaran menggunakan modul membuat peserta didik mudah menemukan konsep, membangkitkan minat belajar, aktif dan berpikir kreatif dibandingkan pembelajaran tanpa menggunakan modul ${ }^{[9]}$. Modul berbasis GDL dapat meningkatkan sikap ilmiah dan pemikiran kritis siswa $^{[10]}$, efektif terhadap prestasi siswa di SMA unggulan $^{[11]}$. Motivasi dan hasil belajar siswa juga meningkat dengan menggunakan modul berbasis GDL $^{[12-13]}$. Hal ini disebabkan karena modul disusun berdasarkan sintaks model GDL yang memudahkan peserta didik dalam memahami materi. Materi kimia yang diajarkan di kelas XI SMA salah satunya adalah kesetimbangan kimia.

Pada materi ini telah tersedia modul kesetimbangan kimia berbasis GDL. Modul ini telah dilakukan uji validitas dan praktikalitas, namun belum dilakukan uji efektivitas terhadap hasil belajar, maka dilakukan penelitian untuk menganalisis efektivitas modul kesetimbangan kimia berbasis GDL terhadap hasil belajar peserta didik SMAN 1 Tigo Nagari.

\section{METODE}

Penelitian dilakukan pada bulan November 2019 di SMAN 1 Tigo Nagari dengan populasi dari peserta didik kelas XI tahun ajaran 2019/2020. Sampel diambil menggunakan teknik simple random sampling ${ }^{[14]}$, sehingga didapatkan dua kelas sampel yaitu kelas kontrol XI MIPA 3 dan kelas eksperimen XI MIPA 1. Metode penelitian menggunakan eksperimen semu (quasi experiment) dan rancangan randomized control-group pretest-posttest design ditampilkan pada Tabel 1.
Tabel 1. Rancangan Penelitian.

\begin{tabular}{c|c|c|c}
$\mathbf{R}$ & Pretest & Perlakuan & Posttest \\
\hline $\begin{array}{c}\text { Kelas } \\
\text { eksperimen }\end{array}$ & $\mathrm{T} 1$ & $\mathrm{X}$ & $\mathrm{T} 2$ \\
\hline $\begin{array}{r}\text { Kelas kontrol } \\
\text { Berdasarkan }\end{array}$ & $\mathrm{T} 1$ & - & $\mathrm{T} 2$ \\
rancangan & penelitian
\end{tabular}

(Tabel 1 ) dengan $\mathrm{R}=$ kelas sampel; $\mathrm{X}=$ pembelajaran menggunakan modul berbasis GDL; T1 = Pretest; $\mathrm{T} 2$ = Posttest . Kelas eksperimen belajar menggunakan modul GDL, sedangkan kelas kontrol dibelajarkan seperti guru membelajarkan biasanya dengan menggunakan RPP guru di sekolah uji coba. Kedua kelas sampel diberikan pretest dan posttest berupa tes objektif. Soal tes yang digunakan telah memiliki daya pembeda, valid, reliabel dan indeks kesukaran soal, yang telah memenuhi kriteria soal baik ${ }^{[15]}$. Hasil penelitian diolah menggunakan uji $n$-gain dan uji hipotesis.

\section{HASIL DAN DISKUSI}

\subsection{Hasil}

Hasil penelitian diperoleh dari pretest dan posttest sebagai hasil belajar pada ranah kognitif. Hasil yang didapatkan ditampilkan pada Gambar 1. Dari Gambar 1 dapat dilihat bahwa kelas eksperimen menghasilkan nilai yang lebih tinggi. Untuk menganalisis hasil belajar kelas sampel berbeda secara nyata, harus melakukan uji statistik (uji hipotesis).

\subsubsection{Uji n-gain}

Uji $n$-gain dilakukan untuk menyatakan tingkat keefektifan dari modul kesetimbangan kimia berbasis GDL. Hasil uji n-gain kedua kelas sampel yang diperoleh ditampilkan pada Tabel 2 .

Tabel 2. Hasil $n$-gain Kelas Sampel.

\begin{tabular}{c|c|c|c} 
Kelas & $\mathbf{N}$ & Rata-rata -gain & Kategori \\
\hline Eksperimen & 31 & 0,35 & Sedang \\
\hline Kontrol & 29 & 0,25 & Rendah
\end{tabular}

Data pada Tabel 2 menunjukkan kelas kontrol menghasilkan nilai $n$-gain yang lebih rendah daripada kelas eksperimen. Uji hipotesis membuktikan hasil belajar kelas sampel berbeda secara signifikan. Syarat untuk melakukan uji hipotesis harus melakukan uji homogenitas dan normalitas ${ }^{[16]}$.

\section{Hasil Belajar Kelas Sampel \\ dalam bentuk Rentang Nilai (Pretest dan Posttest)}
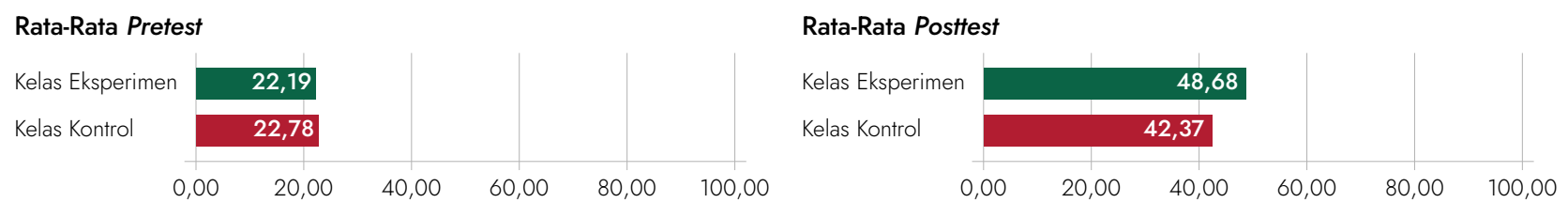

Gambar 1. Hasil Belajar Kelas Sampel (pretest dan posttest). 


\subsubsection{Uji Normalitas}

Hasil uji normalitas ditampilkan pada Tabel 3. Dari Tabel 3 terlihat bahwa kedua kelas sampel terdistribusi normal dengan ketentuan besar dari taraf $\alpha 0,05$.

Tabel 3. Hasil Uji Normalitas Kelas Sampel.

\begin{tabular}{c|c|c|c} 
Kelas & $\boldsymbol{\alpha}$ & $\mathbf{( s i g )}$ & Keputusan \\
\hline Eksperimen & \multirow{2}{*}{0,05} & 0,18 & $\begin{array}{c}\text { Terdistribusi } \\
\text { normal }\end{array}$
\end{tabular}

\subsubsection{Uji Homogenitas}

Pada Tabel 4 menampilkan hasil uji homogenitas. Dari Tabel 4 terlihat bahwa data hasil belajar kelas sampel terdistribusi homogen.

Tabel 4. Hasil Uji Homogenitas Kelas Sampel.

\begin{tabular}{c|c|c|c} 
Kelas & $\boldsymbol{\alpha}$ & $\mathbf{( s i g )}$ & Kesimpulan \\
\hline Eksperimen & 0,05 & 0,93 & $\begin{array}{c}\text { Terdistribusi } \\
\text { homogen }\end{array}$
\end{tabular}

\subsubsection{Uji Hipotesis}

Pada Tabel 5 menampilkan hasil uji hipotesis. Dari Tabel 5 menunjukkan bahwa hipotesis penelitian diterima dengan kata lain kelas sampel mempunyai perbedaan peningkatan hasil belajar yang signifikan.

Tabel 5. Hasil Uji Hipotesis Kelas Sampel.

\begin{tabular}{c|c|c} 
Kelas & Sig (2-tailed) & Keputusan \\
\hline Eksperimen & 0,003 & $\begin{array}{c}\mathrm{H}_{0} \text { ditolak } \\
\mathrm{H}_{1} \text { diterima }\end{array}$
\end{tabular}

\subsubsection{Analisis Lembar Kegiatan (LK)}

dan Lembar Kerja Peserta didik (LKPD)

Hasil belajar kelas eksperimen juga dilihat dari setiap LK dan LKPD yang terdapat pada modul. Penilaian LK dan LKPD disesuaikan dengan rubrik penilaian dan indikator pencapaian kompetensi. Hasil penilaian dari LK dan LKPD ditampilkan pada Tabel 6 .

Tabel 6. Nilai Lembar Kegiatan dan Lembar Kerja Peserta Didik.

\begin{tabular}{c|c|c|c}
$\begin{array}{c}\text { Pertemuan } \\
\text { ke- }\end{array}$ & $\begin{array}{c}\text { Lembar } \\
\text { Kegiatan }\end{array}$ & $\begin{array}{c}\text { Lembar } \\
\text { Kerja }\end{array}$ & $\begin{array}{c}\text { Nilai } \\
\text { Akhir }\end{array}$ \\
\hline 1 & 91 & 87,2 & 89,5 \\
\hline 2 & 88 & 82,1 & 85,6 \\
\hline 3 & 87,4 & 84,8 & 86,4 \\
\hline Rata-rata & $\mathbf{8 8 , 8}$ & $\mathbf{8 4 , 7}$ & $\mathbf{8 7 , 2}$
\end{tabular}

Nilai akhir didapatkan dari 60\% lembar kegiatan dan 40\% lembar kerja (LKPD). Berdasarkan Tabel 6 dapat dilihat bahwa adanya perbedaan ratarata lembar kegiatan dan lembar kerja pada setiap pertemuan. Hal ini disebabkan materi pada setiap pertemuannya lebih spesifik.

\subsection{Pembahasan}

Berdasarkan analisis data diperoleh kedua kelas sampel memiliki kemampuan awal yang hampir sama (Gambar 1). Untuk menganalisis pengetahuan awal yang dimiliki oleh peserta didik maka di awal pembelajaran diberikan pretest. Pengetahuan awal dari peserta didik berguna dalam membantu guru untuk memperkirakan bagian materi mana yang harus diajarkan lebih mendalam, sehingga waktu yang digunakan saat pembelajaran akan lebih efektif ${ }^{17]}$.

Pada kedua kelas sampel diberikan posttest pada akhir pembelajaran untuk menganalisis kemampuan peserta didik pada ranah kognitif. Berdasarkan hasil posttest kelas sampel (Gambar 1) menunjukkan adanya peningkatan hasil belajar dari yang sebelumnya. Setelah nilai pretest dan posttest didapatkan peneliti melakukan analisis data $n$-gain.

Berdasarkan analisa n-gain (Tabel 2) menghasilkan nilai $n$-gain yang tinggi pada kelas eksperimen dengan kategori sedang. Hal ini menunjukkan terjadinya peningkatan hasil belajar peserta didik yang lebih baik pada kelas eksperimen yang menggunakan modul kesetimbangan kimia berbasis GDL dibandingkan kelas kontrol.

Setelah mendapatkan nilai n-gain maka dilakukan uji homogenitas (Tabel 4) dan normalitas (Tabel 3) didapatkan data variasi homogen dan normal maka dilakukan uji hipotesis menggunakan independent $t$-test. Pada uji hipotesis (Tabel 5) didapatkan nilai sig (2-tailed) $<0,05$ yang menunjukkan hipotesis penelitian diterima dengan kata lain penggunaan modul kesetimbangan kimia berbasis GDL efektif terhadap peningkatan hasil belajar peserta didik.

Penelitian lain juga mengungkapkan penggunaan modul GDL efektif terhadap motivasi dan hasil belajar dalam proses pembelajaran[ $\left.{ }^{8-12,18}\right]$. Peserta didik kelas eksperimen lebih mudah mengikuti pembelajaran, karena dituntun oleh modul melalui tahapan-tahapan GDL untuk menemukan dan membentuk konsep baru yang dipelajari ${ }^{[19]}$. Hal ini sejalan dengan teori belajar konstruktivisme yang mengungkapkan pembelajaran dapat berjalan dengan efektif apabila peserta didik dapat membangun dan membentuk sendiri konsep yang dipelajari.

Hasil belajar tidak hanya menjadi pedoman utama dalam pembelajaran tetapi juga memperhatikan proses belajar ${ }^{[20]}$. Hasil belajar kelas eksperimen didukung oleh nilai peserta didik dalam menjawab lembar kegiatan dan lembar kerja peserta didik pada modul (Tabel 6). Rata-rata lembar kegiatan mengalami penurunan pada tiap pertemuan yang disebabkan oleh peserta didik yang kesulitan matematika dan keterbatasan waktu, pada pertemuan kedua materi yang dipelajari lebih banyak hitung-hitungan. Pada pertemuan ketiga dilakukan percobaan, pada percobaan banyak membutuhkan waktu yang disebabkan oleh peserta 
didik kurang memahami cara penggunaan alat-alat laboratorium. Hasil analisis lembar kegiatan dan lembar kerja didapatkan rata-rata lembar kegiatan sebesar 88,8 dan rata-rata lembar kerja sebesar 84,7 sehingga didapatkan rata-rata nilai akhir lembar kegiatan dan lembar kerja sebesar 87,2.

Berdasarkan pembahasan di atas, penggunaan modul berbasis GDL merupakan salah satu faktor meningkatnya hasil belajar dan pemahaman peserta didik. Penelitian lain juga mengungkapkan pembelajaran dengan menggunakan modul berbasis GDL mampu meningkatkan keterampilan berpikir kritis dan hasil belajar peserta didik ${ }^{[21]}$.

\section{SIMPULAN}

Berdasarkan hasil penelitian dan analisa data didapatkan kesimpulan bahwa adanya peningkatan hasil belajar peserta didik dalam proses pembelajaran yang menggunakan modul kesetimbangan kimia berbasis GDL.

\section{REFERENSI}

1. Kementerian Pendidikan dan Kebudayaan Republik Indonesia. Peraturan Menteri Pendidikan dan Kebudayaan Nomor 22 Tahun 2016 tentang Standar Proses Pendidikan Dasar dan Menengah. Jakarta: Kementerian Pendidikan dan Kebudayaan Republik Indonesia; 2016.

2. Maulidar N, Yusrizal, Halim A. Pengaruh Penerepan Model Pembelajaran Guided Discovery Terhadap Kemampuan Pemahaman Konsep dan Keterampilan Berpikir Kritis Siswa SMP Pada Materi Kemagnetan. Jurnal Pendidikan Sains Indonesia [Internet] 2016;04(02):69-75. Available from: http:// www.jurnal.unsyiah.ac.id/JPSI/article/ view/7581

3. Janssen F, Westbroek H, van Driel J. How to make guided discovery learning practical for student teachers. Instructional Science [Internet] 2013;42(1):67-90. Available from: https://link.springer.com/article/10.1007/ s11251-013-9296-Z

4. Noorrohman S. Peningkatan Keaktifan Siswa Melalui Model Pembelajaran Guided Discovery Pada Mata Pelajaran IPA. Basic Education [Internet] 2018;7(30). Available from: http:// journal.student.uny.ac.id/ojs/index.php/pgsd/ article/view/13516

5. Sulistyowati N, Widodo A, Sumarni W. Efektivitas Model Pembelajaran Guided Discovery Learning Terhadap Kemampuan Pemecahan Masalah Kimia. Chemistry in Education [Internet] 2012;01(02):49-55. Available from: https://journal.unnes.ac.id/ sju/index.php/chemined/article/view/980

6. Alabi T, Nureni L. Effects of Guided Discovery and Problem Solving on Achievement of Secondary School Students' in Volumetric Analysis in Niger State. ATBU Journal of Science, Technology and Education [Internet]
2016;03(04). Available from: https://www. atbuftejoste.com/index.php/joste/article/ view/166

7. Udo M. Effect of Guided-Discovery, StudentCentred Demonstration and the Expository Instructional Strategies on Students' Performance in Chemistry. African Research Review [Internet] 2010;4(4). Available from: https://www.ajol.info/index.php/afrrev/ article/view/69237

8. Abdisa G, Getinet T. The effect of guided discovery on students' Physics achievement. Latin-American Journal of Physics Education [Internet] 2012;06(04):530-537. Available from: http://www.lajpe.org/dec2012/4 LAJPE_715_Tesfaye_Getinet_preprint_corr_f. pdf

9. Lasmiyati, Harta I. Pengembangan Modul Pembelajaran untuk Meningkatkan Pemahaman Konsep dan Minat SMP. Pythagoras: Jurnal Pendidikan Matematika [Internet] 2014;9(2):161-174. Available from: https://journal.uny.ac.id/index.php/ pythagoras/article/view/9077

10. Perwitasari N, Djukri. Developing thematicintegrated module based on guided discovery to improve critical thinking and student science attitude. Jurnal Prima Edukasia [Internet] 2018;6(1):44-55. Available from: https://journal.uny.ac.id/index.php/jpe/ article/view/15218

11. Khabibah E, Kuswanti N, Suparno G. Keefektifan Modul Berbasis Guided Discovery pada Materi Respiratory System [Internet]. In: Prosiding Seminar Nasional Pendidikan IPA. Malang: Pascasarjana Universitas Negeri Malang (UM); 2016. page 764-770.Available from: http://pasca.um.ac.id/wp-content/ uploads/2017/02/Elok-Norma-K.-764-770.pdf

12. Yerimadesi, Putra A, Ririanti. Efektivitas Penggunaan Modul Larutan Penyangga Berbasis Discovery Learning terhadap Hasil Belajar Siswa Kelas XI MIA SMAN 7 Padang. JURNAL EKSAKTA PENDIDIKAN (JEP) [Internet] 2017;1(1):17-23. Available from: http://jep.ppj.unp.ac.id/index.php/jep/article/ view/29

13. Yerimadesi, Bayharti, Azizah, Lufri, Andromeda, Guspatni. Effectiveness of acidbase modules based on guided discovery learning for increasing critical thinking skills and learning outcomes of senior high school student. Journal of Physics: Conference Series [Internet] 2019;1185:012151. Available from: https://iopscience.iop.org/ article/10.1088/1742-6596/1185/1/012151

14. Lufri. Metodologi Penelitian. Padang: FMIPA UNP; 2005.

15. Arikunto S. Dasar-Dasar Evaluasi Pendidikan. Jakarta: Bumi Aksara; 2013.

16. Santoso S. Panduan Lengkap SPSS Versi 23. Jakarta: Elex Media Komputindo; 2016. 
17. Gazali F, Yusmaita E. Analisis Prior Knowledge Konsep Asam Basa Siswa Kelas XI SMA untuk Merancang Modul Kimia Berbasis REACT. JURNAL EKSAKTA PENDIDIKAN (JEP) [Internet] 2018;2(2):202. Available from: http://jep.ppj.unp.ac.id/index.php/jep/article/ view/249

18. Yerimadesi, Kiram Y, Lufri, Festiyed. Development of guided discovery learning based module on colloidal system topic for senior high school. Journal of Physics: Conference Series [Internet] 2018;1116:042044. Available from: https://iopscience.iop.org/ article/10.1088/1742-6596/1116/4/042044

19. Olorode J, Jimoh A. Effectiveness of Guided Discovery Learning Strategy and Gender Sensitivity on Students' Academic Achievement in Financial Accounting in Colleges of Education. International Journal of Academic Research in Education and Review [Internet] 2016;4(6):182-189. Available from: http://www.academicresearchjournals. org/IJARER/Abstract/2016/December/ OLORODE\%20AND\%20JIMOH.htm

20. Sudjana N. Dasar-Dasar Proses Belajar Mengajar. 13th ed. Bandung: Sinar Baru Algensindo; 2011.

21. Bayharti, Azumar O, Andromeda, Yerimadesi. Effectiveness of redox and electrochemical cell module based guided discovery learning on critical thinking skills and student learning outcomes of high school. Journal of Physics: Conference Series [Internet] 2019;1317:012144. Available from: https://iopscience.iop.org/ article/10.1088/1742-6596/1317/1/012144 